\title{
HYPERCALCAEMIA AND CANCER
}

\author{
Lyal Watson, M.B., B.S., M.R.A.C.P. \\ B.E.C.C. Research Fellow \\ From the Medical Unit, University College Hospital, London, W.C.I
}

MANY cancer patients develop a raised plasma calcium at some time during the course of their illness. This has been emphasized by several workers including Swyer, Berger, Gordon and Laszlo (1950), Woodard (1953), Myers (1960), Warwick, Yendt and Olin (1961). Some cancers present with hypercalcæmia and cause considerable difficulty in differential diagnosis (David, Verner and Engel, 1962).

The symptoms of hypercalcæmia include lethargy, muscular weakness and hypotonia, anorexia, nausea, vomiting, constipation, dry mouth, thirst, polyuria and a variety of mental changes. These symptoms, which may be the major source of invalidity in hypercalcæmic cancer patients, can usually be relieved by measures which include cortisone administration, ablative endocrine surgery, hormone therapy, radiotherapy and occasionally by surgical removal of the tumour.

Cancerous hypercalcæmia is usually associated with bony metastases and in such cases it is probably due to erosion of bone by actively growing tumour cells, but the mechanisms are not always clear. Morbid anatomists of the last century recognized that certain cancers (particularly of the breast, lung and kidneys) had a special tendency to metastasize to bone. When chemical analytical methods became available in the earlier years of this century, attention was focussed on the chemical changes associated with this bony invasion and in 1936 Gutman, Tyson and Gutman showed that hypercalcamia occurred in multiple myeloma and neoplastic disease involving bone. Many other studies followed.

\section{Calcium Metabolism}

The three main sites of regulation of calcium and phosphorus metabolism, as at present understood, are the intestine which is the portal of entry, the bones which are the storehouse and the kidneys which provide the excretory channel. Although it varies a good deal, the daily intake of calcium is commonly about 1,000 mg., of which the net absorption is only 100 to $250 \mathrm{mg}$. Since normal adults are in calcium balance the urinary excretion is equal to the net absorption of 100 tn $25^{\circ}$ mg. per day; $99 \%$ of the total calcium in the body is stored in the skeleton, but bone is a dynamic tissue in

A paper read to the Harveian Society of London on April 17, 1963. which continuous deposition and resorption is asso-. ciated with a large daily turnover of calcium between $\overrightarrow{\vec{\omega}}$ bone and bloodstream.

Several reviews of calcium metabolism, includingo those of Dent (1956) and Watson (1960), have emphasized that the plasma calcium is one of the important body constants which is normally maintained within aw relatively narrow range despite these large daily ex-changes of calcium between bone and bloodstream andor from intestine to bloodstream to kidney.

Two chief physiological devices which contribute to $f$ this are the parathyroid secretions and vitamin $D$. Probably the chief function of the parathyroid glands $\triangle$ is to regulate the mobilization of calcium from bone to bloodstream in order to maintain a normal plasma $Z$ calcium level, while the best known and probably the? most important action of vitamin $D$ is to promote $D$ gastro-intestinal absorption of calcium and this, too, plays an important role in keeping the plasma calcium® normal.

\section{Hypercalcæmia and Bony Secondaries}

It is clear that in cancer patients with widèspread osteolytic lesions hypercalcæmia could result from a disturbance of blood-bone equili-o brium so that a gross excess of calcium passeso from the bones into the bloodstream. Myeloma, $\stackrel{D}{2}$ leukæmia and the reticuloses involving bone $\vec{\circ}$ could all behave similarly.

In 1948 Albright and Reifenstein wrote 'The? most obvious and probably the correct explana-? tion ... of the hypercalcæmia . . . is that theo metastatic lesions are dissolving bone salts into the bloodstream more rapidly than the kidney? can clear the blood of excess calcium'. Subsequent studies have confirmed the validity of this concept, showing that such patients usually have minimal gastro-intestinal absorption but a high urinarys calcium so that they are in negative calcium balance, the whole process being an expression of bony dissolution (Laszlo, Schulman, Bellin, Nㅗ Gottesman and Schilling, I952, Pearson, West, $N$ Hollander and Escher, 1952, Skoog, Adams and MacDonald, 1962). These observations have been confirmed in our own laboratories. Pearson,,$<$ West, Hollander and Treves, (1954) reiteratedo that hypercalcæmia appeared only when the renal excretory capacity for calcium was exceeded,, this capacity being about $500 \mathrm{mg}$. per day when renal function was normal. Others have not always 
found such a neat relationship (for example Baker, 1956) though it is generally agreed that the urinary calcium excretion is a useful measure of the progress or regression of bony metastases. Some observers have recently questioned this view (Gardner and Gordon, 1962).

\section{Hypercalcæmia without Bony Secondaries}

In other cancer cases hypercalcæmia is not associated with demonstrable bony metastases, such patients having no clinical or radiological evidence of bone disease and a normal alkaline phosphatase. Some of them eventually prove to have bony metastases, but in others no secondaries are found and it now seems clear that cancer cells can produce chemical substances which modify calcium and phosphorus metabolism and cause a raised plasma calcium without anatomical invasion of bone tissue by tumour cells.

Some sort of humoral mechanism was postulated as long ago as 1923 by Klemperer and again in 1948 by Albright and Reifenstein, who studied a patient with a hypernephroma and speculated that the tumour produced a 'parathyroid-hormonelike' substance which accounted for the chemical findings. Better evidence came in 1956 when Connor, Thomas and Howard described two patients in whom hypercalcæmia disappeared completely when the primary tumour was removed. In the same year Plimpton and Gellhorn published studies from Io patients with malignant hypercalcæmia without any evidence of invasion of bone. There have since been further case reports which support the idea of a humoral substance (Schatten, Ship, Pieper and Bartter, 1958, Abouav, Berkowitz and Kolb, 1959, Alanis and Flanagan, 1959, Gold and Shnider, 1959, Lucas, I960, Stone, Waterhouse and Terry, I96I, Loebel and Walkoff, 1962, Fry, 1962).

\section{Theories of Humoral Action}

The nature of the substance and its mode of action have been the subject of much speculation. It has been suggested that hypercalcæmia may be due to an abnormal substance which circulates in the bloodstream in combination with calcium and produces, in a sense, a spurious hypercalcæmia. In support of this view Marsh and Walser (196I) reported that the plasma ionised calcium was increased in only half their cases whereas the complexed calcium was often raised. This has not been our experience. Using the method of Rose (1957) we have found increases in both ionised and protein-bound fractions in all hypercalcæmic cancer patients tested and the complexed fraction has always been normal.

Another theory is that the substance may be parathyrotrophic and produce hypercalcæmia by stimulating the parathyroid glands and this is supported by the histological appearance of parathyroid hyperplasia in a few reported cases although the parathyroids have usually been reported as normal. We have not yet found any morphological evidence of parathyroid hyperplasia in our cancer patients.

Other theories have postulated direct peripheral actions and have endeavoured to characterize a substance in terms of known behaviour as vitamin D-like or parathormone-like. Attempts to demonstrate such activity in tumour extracts have so far been unsuccessful. Dr. Cuthbertson performed vitamin $D$ assays on the plasma of several of our patients with normal results. More indirect approaches have also been disappointing, indeed there is no complete or satisfactory balance study from such a patient in the literature. Undoubtedly one of the reasons for this is the difficulty of obtaining standard conditions of dietary intake in hypercalcæmic cancer patients, who are usually troubled by nausea or vomiting.

With the co-operation of the Radiotherapy Department at University College Hospital we have collected for prospective study a group of women with inoperable breast cancer who at the time of selection were clinically well and had no evidence of bony metastases, but who were otherwise unselected. This investigation is current and at the time of writing it includes 45 patients. None of these was hypercalcæmic initially but about one third of them had a urinary calcium excretion above $250 \mathrm{mg}$. per day and $20 \%$ had a pronounced hypercalciuria in excess of $300 \mathrm{mg}$. per day. These patients were selected in such a way as to minimize the incidence of bony metastases and it is likely that in some of them the hypercalciuria is due to a humoral mechanism of the kind which later causes hypercalcæmia. If so, some will later develop a high plasma calcium, but in the meantime it is possible to study them while they are well and suitable subjects for calcium and phosphorus balances.

Balances have been performed in five of these hypercalciuric patients. On a daily intake of about $1000 \mathrm{mg}$. four were in approximate calcium balance and absorbing too much calcium from the diet. In these cases the daily urinary calcium excretions were about $300 \mathrm{mg}$., $350 \mathrm{mg}$., $450 \mathrm{mg}$. and $470 \mathrm{mg}$. After a follow-up of up to two years in the longest cases none has yet developed hypercalcæmia and this long follow-up strengthens the view that they do not have bony secondaries.

This picture is consistent with the action of a vitamin D-like substance, but the results in the fifth patient were quite different. On a daily intake of about $900 \mathrm{mg}$. of calcium she was in 
negative calcium balance of about $45^{\circ} \mathrm{mg}$. per day with a fæcal calcium almost equal to intake and a daily urinary calcium excretion between $45^{\circ} \mathrm{mg}$. and $500 \mathrm{mg}$. This picture is very similar to that we have seen in hypercalcæmic patients with bony metastases, but after 2 I months of close observation during which time the urinary calcium has been constantly in excess of $400 \mathrm{mg}$. per day there is still no evidence of bony secondaries clinically or radiologically and the plasma alkaline phosphatase is normal.

A consideration of the amount of calcium dissolved makes it increasingly unlikely that she has had osteolytic bony secondaries throughout this period for they would be expected by now to produce some local evidence, clinically or radiologically, of activity even though initially small and widespread. On the other hand the whole picture is fully consistent with a humoral action on bone. Furthermore at the time of writing her plasma total calcium and plasma ionised calcium have both risen to the extreme upper limit of normality, though she is well and free of complaints.

We consider that this patient has evidence of a humoral substance, almost certainly arising from cancer cells, which is modifying her calcium and phosphorous metabolism without the celly having invaded bone tissue. It is possible, toos that the other patients have a different humora substance and there may be more than onemechanism for the production of hypercalcæmi in cancer patients by humoral means.

\section{Summary}

(I) Hypercalcæmia, which is not uncommo in cancer patients, is usually associated with osteolytic secondaries in bone. In such cases it is usually due to erosion of bone by actively growing tumour cells and the mechanism is clear.

(2) Less commonly, hypercalcæmia results fron $\vec{w}$ humoral substances produced by tumour celleg which do not invade bone tissue.

(3) The nature and behaviour of these substances are under investigation. There may be more than one humoral mechanism for the production of hypercalcæmia in cancer patients.

I am grateful to Professor C. E. Dent for advice and criticism, to Professor M. L. Rosenheim for support and encouragement, to Dr. G. Hilton and Dr. E. W. Emery of the Radiotherapy Department fob permission to study their cases, and to Dr. W. F. J Cuthbertson (Glaxo Laboratories) for performing the vitamin $\mathrm{D}$ assays.

\section{REFERENCES}

Abouav, J., Berkowitz, S. B., and KolB, F. O. (1959): Reversible Hypercalcæmia in Masculinizing Hypernephroib Tumour of the Ovary: Report of a Case, New Engl. F. Med., 260, ro57.

Alanis, B. F., and Flanagan, J. F. (1959): Myopathy and Hypercalcæmia Occurring with Carcinoma of the Kidney F. Amer. med. Ass., r71, 2076.

Albright, F., and Reifenstein, E. C. (1948): 'Parathyroid Glands and Metabolic Bone Disease'. Baltimore: Williamsీ and Wilkins.

BAKER, W. H. (1956): Abnormalities in Calcium Metabolism in Malignancy: Effects of Hormone Therapy, Amer F. Med., 21, 714 .

Connor, T. B., Thomas, W. C., Jr., and Howard, J. E. (1956): The Etiology of Hypercalcæmia Associated with Lung Carcinoma, $\mathcal{F}$. clin. Invest., 35, 697.

David, N. J., Verner, J. V., and Engel, F. L. (r962): The Diagnostic Spectrum of Hypercalcæmia, Amer. F. Med., $33,88$.

Dent, C. E. (1956): Discussion on Surgical Aspects of Disordered Calcium Metabolism-General Aspects of Calcium and Phosphorus Metabolism with Especial Reference to Surgical Problems, Proc. roy. Soc. Med., 49, 715.

FrY, L. (1962): Pseudohyperparathyroidism with Carcinoma of Bronchus, Brit. med. F., $i$, 301.

GARDNER, B., and Gordon, G. S. (1962): Does Urinary Calcium Excretion Reflect Growth or Regression of Dis seminated Breast Cancer? F. clin. Endocr., 22, 627.

Gold, G. L., and ShNider, B. I. (r959): Some Unusual Syndromes Associated with Neoplastic Disease, Ann. intern Med., 5I, 890 .

Gutman, A. B., Tyson, T. L., and Gutman, E. B. (1936): Serum Calcium, Inorganic Phosphorus and Phosphatase Activity-in Hyperparathyroidism, Paget's Disease, Multiple Myeloma and Neoplastic Disease of the Bones Arch. intern. Med., 57, 379.

Klemperer, P. (1923): Parathyroid Hyperplasia and Bone Destruction in Generalized Carcinomatosis, Surg. Gynec Obstet., 36, 11 .

Laszlo, D., Schulman, C. A., Bellin, J., Gottesman, E. D., and Schilling, A. (1952): Mineral and Protein Metabolism in Osteolytic Metastases, $\mathcal{F}$. Amer. med. Ass., 148, 1027.

Loebel, A. S., and Walkoff, C. S. (1962): Hypercalcæmia in Neoplastic Disease Without Bony Metastases, N.Y.J med. $\mathcal{F}_{.}, 62$, 101 .

LucAs, P. F. (1960): Acute Hypercalcæmia from Carcinomatosis Without Bone Metastasis, Brit. med. F., i, r33o.

MARSH, E. F., Jr., and WALSER, M. (1961): Filtrable Calcium Complexes in the Hypercalcæmia of Malignancy, Clin Res., 9, 205 .

Myers, W. P. L. (1960): Hypercalcæmia in Neoplastic Disease, Arch. Surg., 80, 308.

Pearson, O. H., West, C. D., Hollander, V. P., and Escher, G. C. (1952): Alterations in Calcium Metabolism int Patients With Osteolytic Tumours, F. clin. Endocr., 12, 926. 
med. Ass., I54, 234.

Plimpton, C. H., and Gellhorn, A. (1956): Hypercalcæmia in Malignant Disease Without Evidence of Bone Destruction, Amer. F. Med., 21, 750 .

Rose, G. A. (I957): Determination of the Ionized and Ultrafiltrable Calcium of Normal Human Plasma, Clin. Chim. Acta, 2, 227.

Schatten, W. E., Ship, A. G., Pieper, W. J., and BartTer, F. C. (1958): Syndrome Resembling Hyperparathyroidism Associated with Squamous-cell Carcinoma, Ann. Surg., 148, 890.

Skoog, W. A., Adams, W. S., and MacDonald, N. S. (1962): Metabolic Balance and Sr ${ }^{85} \mathrm{Study}_{\text {of }}$ a Patient with Multiple Myeloma Treated with Corticosteroids and Androgens, Metabolism, II, 421.

Stone, G. E., Waterhouse, C., and Terry, R. (196r): Hypercalcæmia of Malignant Disease: Case Report and a Proposed Mechanism of Etiology, Ann. intern. Med., 54, 977.

SwYer, A. J., Berger, J. S., Gordon, H. M., and LAszlo, D. (I950): Hypercalcæmia in Osteolytic Metastatic Cancer of the Breast, Amer. F. Med., 8, 724 .

WARwick, O. H., YendT, E. R., and Olin, J. S. (I96r): The Clinical Features of Hypercalcæmia Associated with Malignant Disease, Canad. med. Ass. F., 85, 7 r9.

Watson, L. (1960): Calcium Metabolism, Aust. Ann. Med., 9, 326.

Woodard, H. Q. (r953): Changes in Blood Chemistry Associated with Carcinoma Metastatic to Bone, Cancer, .6, 1219. 